\title{
The Effect of Financial Performance on Firm Value Included in the SRI Kehati Index on the Indonesia Stock Exchange, as A Representation of Corporate Behavior
}

\author{
Nila Efrida Yusi \\ Faculty of Economy and Business, Airlangga University, Jl. Airlangga 4-6, Surabaya 60286, Indonesia
}

\begin{abstract}
This research is aimed to examine the effect of Return on Assets (ROA) and Return of Equity (ROE) on the Firm Value which is included in the SRI - Kehati Index category. The study was conducted using secondary data in the form of financial statements of manufacturing companies included in the SRI - Kehati Index listed on the Indonesia Stock Exchange (BEI) in the period 2013 to 2017. Based on signaling theory and using multiple regression, it was found that the two hypotheses tested in this study provide significant results. The results revealed that the financial performance of the SRI - Kehati index, whether measured through ROA or through ROE, affected the firm's value.
\end{abstract}

Keywords: return on assets, return on equity, firm value, SRI index

DOI: $10.7176 /$ RJFA/10-22-13

Publication date: November $30^{\text {th }} 2019$

\section{Introduction}

The development of the industry takes place very rapidly at this time. The company now operates not only profit-oriented, but also pay attention to the social environment. Attention to the social environment is part of the company's triple bottom lines relating to the company's operational guidelines covering economic aspects (profit), social (people), and environment (planet). Companies that pay attention to the social environment tend to have a positive impact with improving the company's image in the eyes of stakeholders (Butler et al., 2011). The company's attention to the environment can also provide non-material benefits for the company, in addition to being a form of awareness of social responsibility.

Various forms of indexes, ratings, and parameters have been developed as an effort to measure corporate social responsibility or commonly referred to as Corporate Social Responsibility (CSR). Substantive growth in Socially Responsible Investment (SRI) or related to investment activities has played an important role in the development of CSR in the last two decades (Déjean et al., 2004 in Slager, 2015).

Investors as stakeholders certainly have a number of considerations when investing. Thus, investors need measurement standards to support them in the decision making process. One of the benchmarks for evaluating a company is its responsibility towards the environment. Regarding the assessment method, the SRI Index will be very relevant to be used. Socially Responsible Investment (SRI) is defined as a set of approaches that includes objectives, social boundaries, ethics, and more conventional criteria regarding the consideration of obtaining, holding or disposing of certain investments (Cowton, 1999 in Déjean et al., 2004).

Socially Responsible Investment (SRI) has been widely used internationally in the international world as a standard for measuring corporate performance in terms of social responsibility. In Indonesia, the SRI was developed by the Kehati Foundation and the Indonesia Stock Exchange (IDX) under another name, namely Sustainability and Responsible Investment or abbreviated as SRI - Kehati on June 8, 2009. The SRI - Kehati index only consists of companies listed on IDX stock exchange. Then, filtering was done based on certain criteria until it was selected to become 25 companies that were constituents of the SRI - Kehati Index. There are 3 (three) main aspects that must be passed by the company in order to be elected as a constituent of the SRI Kehati Index, namely aspects of core business, financial aspects, fundamental aspects. These three aspects outline concern financial performance, corporate governance, human rights, and the company's commitment to the natural and social environment.

Indonesia is a country that is rich in biological natural resources, so it is proper for the business world to play a role in protecting the environment. The company's commitment to the social environment can be important especially in the eyes of local investors because it involves the environment where they stand on this earth. Good corporate behavior will bring good judgment from investors. Through the SRI - Kehati Index, investors are expected to get important information related to social responsibility when deciding to invest in a company, especially those that have been listed on the Indonesia Stock Exchange (IDX).

Studies on the movement of company shares included in the SRI category have been carried out in various parts of the world. Based on various studies of SRI's stock movements it is known that there is no significant difference between the performance of SRI's shares with common shares, as conducted by Phoebus Dhrymes on 464 US shares in the 1991-1996 period. Renneboog (2008) concludes that research guidelines exist but do not 
explicitly indicate that SRI investors are willing to accept suboptimal financial performance to achieve social or ethical goals.

Basalamah \& Jermias (2005) found that reporting on social and environmental audits is carried out by management for strategic reasons, not on the basis of perceived responsibility. The company's actions to report and audit social and environmental activities have increased following threats to the company's legitimacy and sustainable survival. The research also revealed that social and environmental reporting and audits were carried out by organizations other than the accounting profession. Therefore, Basalamah \& Jermias propose that accountants must take part in social and environmental audit reporting activities by providing the expertise they have to this area. Verschoor (1998) shows that there is a statistically significant relationship between management's commitment to social responsibility and financial performance achieved by the company.

Research on the SRI index in Indonesia is still limited. Therefore, this study intends to fill in the blanks about the SRI - Kehati Index and its role. The research theme is related to the influence of Financial Performance measured through Return on Assets (ROA) and Return on Equity (ROE) on Firm Value. The reason for choosing ROA and ROE is because these two ratios are related to company profitability. Ningrum and Leny (2015) state that high ROE tends to reflect high stock prices. The actions of companies that raise the value of ROE are likely to have an impact on rising stock prices. While Harmono (2009, in Kahfi et al, 2018) states that Firm Value is the company's performance which is reflected by stock prices.

\section{Theoretical Background}

\subsection{Signaling Theory}

Signaling Theory arises due to the imbalance of information held between the company's management and shareholders. The company management is the party that has more information related to the company's condition compared to shareholders. Shareholders have very limited information about the condition of the company, so it requires information from the company's management regarding the company's condition, especially relating to company performance. The information obtained in the form of signals of information about the policies that have been taken by management in running the company or through the company's financial statements.

Signaling theory is related to efforts to maximize company value. Signaling Theory discusses the volatility of the prices of shares, bonds and so on in the market, which affects investors' decisions (Fahmi, 2014). Shareholders can obtain information about the company's ability to generate profits through the value of Return on Assets (ROA) or through the value of Return on Equity (ROE) contained in the company's financial statements. Suwardjono (2016) states that one of the information that can be obtained by shareholders is through the publication of the company's financial statements.

\subsection{SRI - Kehati Index}

The Socially Responsible Investment Index (SRI) - Kehati was created by a foundation called Keanekaragaman Hayati Indonesia (Kehati) in collaboration with the Indonesia Stock Exchange (BEI) on June 8, 2009. The Kehati Foundation is the largest non-profit environmental conservation organization in Indonesia formed by a number of figures, activists, and intellectuals who care about the environment who have a great concern for nature conservation. The SRI - Kehati index can be used as an investment benchmark for investors to see which public companies are performing well in their business operations in terms of financial, social and environmental governance in a sustainable manner.

Companies that are constituents of the SRI - Kehati Index are limited to 25 companies, which are selected every two periods of the year. The mechanism for determining which companies will become constituents of the SRI - Kehati Index is carried out through three stages of selection. The initial stage is screening based on aspects of the core business. At this stage, Kehati eliminates companies whose business fields are destructive and pose a threat to the preservation of the natural and social environment. The second stage is screening based on financial aspects. At this stage, Kehati sets some minimum limits related to the financial aspects of the company so that they can become constituents of the SRI - Kehati Index. The third stage is filtering based on fundamental aspects. At this stage there are six indicators that must be met by the prospective SRI-Kehati index constituent companies.

\subsection{Return on Assets (ROA)}

Return on Assets (ROA) is a profitability ratio that illustrates the effectiveness of companies in using all forms of assets owned to obtain profits (Febrioni et al, 2016). Return on Assets (ROA) is also often referred to as Return on Investment (ROI). ROA is used to measure the level of profit that can be generated from each asset invested (Setyorini et al, 2016). Thus, it can be concluded that the higher the value of ROA achieved, the better the level of effectiveness of the company in using its assets. Amalya (2018) says that ROA is the most important ratio among all other profitability ratios. 


$\frac{\mathrm{ROA}}{\text { Earning After Tax }}$
Total Asset
I

\subsection{Return on Equity (ROE)}

Return of Equity (ROE) is a profitability ratio that is used to measure the company's ability to provide benefits for shareholders (Mandala and Ayu, 2016). ROE value calculation is by dividing net income or earnings after tax (EAT) with total equity. An increase in net profit has an impact on increasing the value of ROE, so that new investors will be interested in buying these shares, which eventually the company's stock price has increased (Ningrum and Leny, 2015). It can also be said that the higher the value of ROE, the better the company's ability to provide profits to shareholders. In addition, the value of ROE also shows the level of effectiveness and efficiency of the company in using its capital to achieve certain profits.

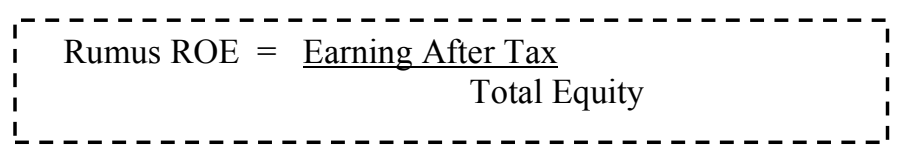

\subsection{Firm Value}

Husnan and Pudjiastuti (2006, in Octrima, 2017) explained that the value of the company is the price that potential buyers can pay if the company is sold. For companies that issue shares in the capital market, the price of shares traded on the stock exchange is an indicator of firm value. Tobin's Q is often used to calculate the value of a company. Fiakas (2005, in Sudiyatno \& Elen, 2010) states that Tobin's Q is the ratio of the market value of the company's assets as measured by the market value of the number of shares outstanding and debt to the total assets of the company formulated as follows:

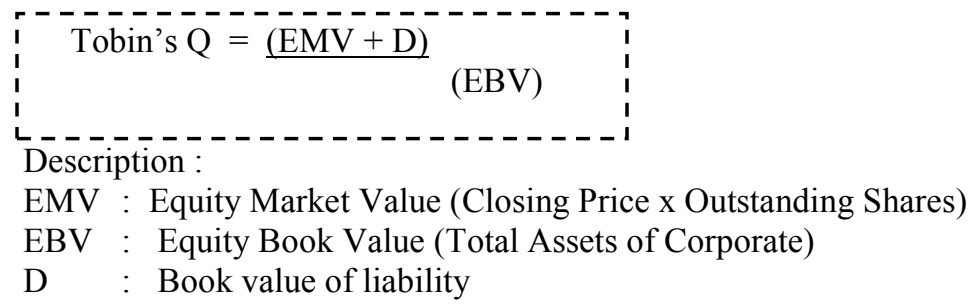

\subsection{Prior Research}

There are previous studies that can be used as comparative data or reference material for research currently being conducted. Pirie \& Smith (2008) states that a company's financial performance influences firm value. Kahfi et al (2018) conducted a study related to the effect of Return on Equity (ROE) on firm value. The sample of companies used is the type of food and beverage manufacturing companies listed on the Indonesia Stock Exchange (BEI) for the period 2011-2016. The results of this study indicate that ROE has no effect on firm value. Sugiarto \& Perdana (2017) also examined the relationship between Return On Equity (ROE) and firm value. The difference is, the sample used in the study is property sector companies listed on the Indonesia Stock Exchange (IDX). The results of the study also showed that ROE had a negative effect on firm value.

Research related to the effect of Return on Equity (ROE) on firm value with different results from the two studies above, conducted by Nurminda et al (2017). The research shows that ROE significantly influences firm value. The sample of companies used are manufacturing companies engaged in the goods and consumption subsector listed on the Indonesia Stock Exchange (IDX) for the 2012-2015 period.

Research on the effect of Return on Assets (ROA) on company value was conducted by Oktrima (2017). The research was conducted at PT Mayora Indah from 2011 to 2015. The results showed that there was no effect of ROA on the value of the company being tested. Based on some of the studies above that serve as comparative data and reference material, a hypothesis arises about the effect of Return on Assets (ROA) and Return on Equity (ROE) on the value of companies included in the SRI-Kehati Index category.

\subsection{Research Hypothesis}

The hypotheses in this study are:

$\mathrm{H}_{1}$ : Return on Assets (ROA) affect the firm value of the company included in the SRI Kehati Index.

$\mathrm{H}_{2}$ : Return on Equity (ROE) affect the firm value of the company included in the SRI Kehati Index. 


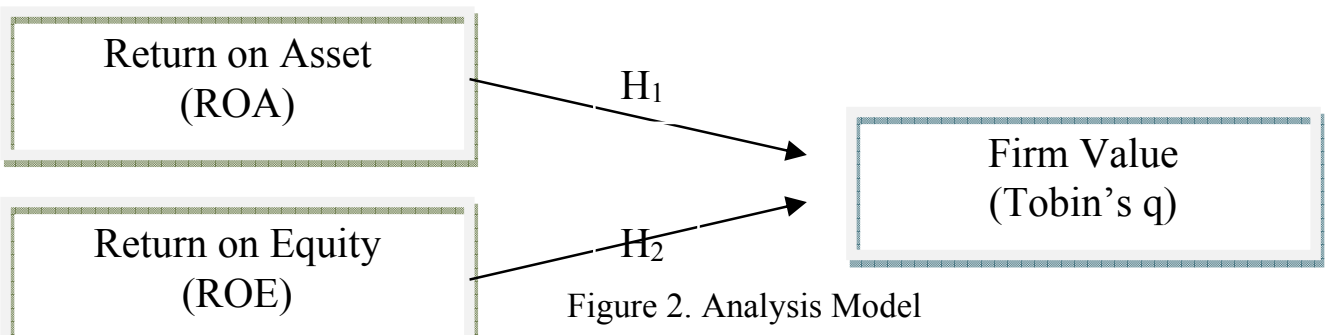

\section{Research Methods}

This research is a type of quantitative research. The data used are secondary data in the form of financial statements of manufacturing companies listed on the Indonesia Stock Exchange (IDX) in the period 2013 to 2017. Sampling is done by purposive sampling, so that only the appropriate samples are included in the SRI Index index - Kehati course will be used in this study.

The SRI - Kehati index selects companies as their constituents for two periods per year. Every period there are 25 companies taken as constituents. During the 10 reporting periods of the SRI - Kehati Index within a period of 5 years, from 2013 to 2017, there were 19 companies that continued to be consistently involved. All consistent companies will be used in this research.

Table 1. List of Sri Kehati index companies used in this study

\begin{tabular}{|l|l|l|l|}
\hline No & \multicolumn{1}{|c|}{ Company Name } & No & \multicolumn{1}{|c|}{ Company Name } \\
\hline 1. & PT Astra Agro Lestari Tbk & 11. & PT Bank Mandiri (Persero) Tbk \\
\hline 2. & PT Adhi Karya (Persero) Tbk & 12. & PT Indofood Sukses Makmur Tbk \\
\hline 3. & PT Astra International Tbk & 13. & PT Jasa Marga (Persero) Tbk \\
\hline 4. & PT Bank Central Asia Tbk & 14. & PT Kalbe Farma Tbk \\
\hline 5. & PT Bank Negara Indonesia (Persero) Tbk & 15. & PT PP London Sumatra Indonesia Tbk \\
\hline 6. & PT Bank Rakyat Indonesia (Persero) Tbk & 16. & PT Perusahaan Gas Negara (Persero) Tbk \\
\hline 7. & PT Bank Danamon Indonesia Tbk & 17. & PT Pembangunan Jaya Ancol Tbk \\
\hline 8. & PT Semen Indonesia (Persero) Tbk & 18. & PT Timah (Persero) Tbk \\
\hline 9. & PT Telekomunikasi Indonesia (Persero) Tbk & 19. & PT United Tractors Tbk \\
\hline 10. & PT Unilever Indonesia & & \\
\hline
\end{tabular}

Source : www.kehati.or.id

In this study, there are 3 (three) variables, namely Return on Assets (ROA) and Return on Equity (ROE) as independent variables and Firm Value as the dependent variable. The firm value variable is measured using Tobin's q. For testing hypotheses, researchers used regression analysis techniques.

\section{Analysis and Discussion}

\subsection{Descriptive Analysis}

The SRI - Kehati index companies used in this study were 19 companies. The observation year is 5 years, which is the range of 2013-2017. Total observations were 95 observations. The minimum ROA value of the 95 observations is 0.010944 and the maximum 0.401838 , with an average ROA of 0.08385335 . The minimum ROE value is 0.018909 and the maximum value is 1.358487 , with an average of 0.20856220 . Based on research data, all companies included in the SRI - Kehati index have good financial performance seen from the value of ROA and ROE because all of them have positive performance, meaning all of these companies during the observation period always gain profits and no one loses.

The minimum value of Tobin's $q$ is 0.826508 and the maximum value is 23.285751 , with an average of 2.60302192. Tobin's average q value of 2.60302192 means that on average, companies that have an SRI - Kehati index are rated 2 times higher than the book value by the market. All of these company values show positive numbers and are higher than the book value, so it can be said that the market is valuing the company well or the company is able to attract market interest. These values can be specified according to those listed in the following table :

Table 2 : Descriptive of Sri Kehati index company for 2013-2017

\begin{tabular}{|l|c|l|l|l|l|}
\hline & N & \multicolumn{1}{|c|}{ Minimum } & Maximum & Mean & Std. Deviation \\
\hline ROA & 95 & 0,010944 & 0,401838 & 0,08385335 & 0,086310683 \\
\hline ROE & 95 & 0,018909 & 1,358487 & 0,20856220 & 0,263411759 \\
\hline Tobin's q & 95 & 0,826508 & 23,285751 & 2,60302192 & 4,005459072 \\
\hline Valid N (listwise) & 95 & & & & \\
\hline
\end{tabular}




\subsection{Regression Analysis}

The next stage is to do a regression analysis to obtain the coefficient value and see the significance of the regression coefficient. The analysis was carried out using the help of the SPSS statistical program.

Table 3 : Regression analysis result with SPSS

\begin{tabular}{|c|c|c|c|c|c|c|}
\hline \multirow{2}{*}{\multicolumn{2}{|c|}{ Model }} & \multicolumn{2}{|c|}{ Unstandardized Coefficients } & \multirow{2}{*}{$\begin{array}{c}\text { Standardized } \\
\text { Coefficients } \\
\text { Beta } \\
\end{array}$} & \multirow[t]{2}{*}{$\mathrm{t}$} & \multirow[t]{2}{*}{ Sig. } \\
\hline & & $\mathrm{B}$ & Std. Error & & & \\
\hline \multirow[t]{3}{*}{1} & (Constant) & $-0,686$ & 0,155 & & $-4,410$ & 0,000 \\
\hline & ROA & 10,661 & 2,739 & 0,230 & 3,892 & 0,000 \\
\hline & ROE & 11,482 & 0,898 & 0,755 & 12,793 & 0,000 \\
\hline
\end{tabular}

The mathematical equation:

Firm Value $=-0,686+10,661$ ROA $+11,482$ ROE

Constants show negative signs, meaning that if ROA and ROE are each zero, then the value of the company is $-0,686$. Increasing the value of ROA and ROE will increase the firm value.

4.2.1 Hipotesis Testing 1

$\mathrm{H}_{1}$ : Return on Assets (ROA) affect the firm value of the company included in the SRI - Kehati Index.

Testing the effect of ROA on the firm value of companies included in the SRI - Kehati Index produces a p-value $=0,000$. The p-value $<\alpha=0.05$ is significant, so hypothesis 1 is accepted. Hypothesis 1 is accepted, which means Return on Assets (ROA) affects the value of the companies included in the SRI - Kehati Index category. The coefficient value of 10.661 indicates that every increase in ROA will be followed by an increase in the value of the company by 10.661 times, assuming the other variables are constant.

4.2.2 Hypothesis Testing 2

$\mathrm{H}_{2}$ : Return on Equity (ROE) affect the firm value of the company included in the SRI - Kehati Index.

Testing the effect of ROE on the firm value included in the SRI - Kehati Index category produces a p-value = 0,000 . The $p$-value $<\alpha=0.05$ is significant, so hypothesis 1 is accepted. Hypothesis 1 is accepted, which means Return on Equity (ROE) influences the value of companies that fall into the SRI - Kehati Index category. The coefficient value of 11.482 indicates that each increase in ROE will be followed by an increase in the value of the company by 11.482 times, assuming the other variables are constant.

\subsection{Discussion}

Testing the effect of ROA and ROE on company value both gives significant results, as described previously. 4.3.1 Return of Asset (ROA) affect the firm value of the company included in the SRI - Kehati Index.

Testing the effect of Return of Assets (ROA) on company value gives significant results with a p-value of 0,000 $<\alpha=0.05$. ROA measures the ability of company management to manage a company by utilizing assets or resources owned by the company. These resources are managed by the company to maximize shareholder prosperity. The managed resources include tangible as well as intangible resources owned by the company.

Testing the effect of ROA on firm value shows significant results, meaning that changes in ROA significantly influence changes in the firm value. This significance is consistent with signal theory or signaling theory. Signal theory deals with how investors or shareholders need knowledge about the company's financial condition, especially about the performance and profits of the company. Knowledge of accounting profits is important for investors (Suwardjono, 2016). A good company performance will attract investors to invest their capital in the company. This study supports previous research conducted by Pirie \& Smith (2008) that a company's financial performance influences firm value.

The results of research on companies included in the SRI - Kehati index category have a significant influence on company ROA on firm value. This is because stakeholders tend to value companies that pay attention to the social environment positively and cause an increase in the company's image (Butler et al., 2011). 4.3.2 Return of Equity (ROE) affect the firm value of the company included in the SRI - Kehati Index.

Testing the effect of Return of Equity (ROE) on company value gives significant results with a p-value of $0,000<\alpha=0.05$. ROE measures the company's ability to generate profits by utilizing equity or own capital owned by the company. Some people like the use of ROE to assess a company's financial performance because the calculation of performance with ROE is only based on the company's own capital. ROE more reflects the company's ability to make profits just by relying on its own capital, without debt. The results of this study support the research conducted by Nurminda et al (2017) which shows a significant ROE effect on firm value.

The SRI index is a form of bond or shareholder activity, which expects more attention from companies towards social and environmental responsibility (Revelli \& Viviani, 2013). Social and environmental responsibility given by the company is able to attract a positive image of the market, so ROE generates positive numbers and significantly influences the value of the company. This is evidenced by the positive ROE for 5 periods of observation and also by the value of the company that exceeds the book value of the company. 


\section{Conclusion}

The hypotheses tested in this study consisted of 2 (two) hypotheses and both showed significant results. Hypothesis 1 which examines the effect of Return of Assets (ROA) on Company Value included in the SRI Kehati Index category shows positive and significant results. Hypothesis 2 which examines the effect of Return of Equity (ROE) affects the Company Value included in the SRI - Kehati Index category also shows significant results.

\section{References}

Amalya, N. T. (2018). The effect of return on assets, return on equity, net profit margin and debt to equity ratio on stock prices. Jurnal SEKURITAS (Stocks, Economics, Finance and Investment), 1(3).

Basalamah, A. S., \& Jermias, J. (2005). Social and environmental reporting and auditing in Indonesia: maintaining organizational legitimacy?. Gadjah Mada International Journal of Business, 7(1), 109-127.

Butler, J. B., Henderson, S. C., \& Raiborn, C. (2011). Sustainability and the balanced scorecard: Integrating green measures into business reporting. Management Accounting Quarterly, 12(2), 1.

Déjean, F., Gond, J. P., \& Leca, B. (2004). Measuring the unmeasured: An institutional entrepreneur strategy in an emerging industry. Human relations, 57(6), 741-764.

http://csrindonesia.com

https://www.kehati.or.id/indeks-sri-kehati

Kahfi, M. F., Dudi, P., \& Wiwin, A. (2018). Effect of Current Ratio, Debt to Equity Ratio, Total Assets Turnover and Return n Equity to The Value of The Company. Journal of Management, 5(1), $566-574$.

Fahmi, I. (2014). Corporate Financial Management and Capital Markets. First edition. Jakarta : Mitra Wacana Media.

Febrioni, R., Isynuwardhana, D., \& Nazar, M. R. (2016). The Influence of Return On Assets, Return On Equity, Earning Per Share, and Current Ratio Against Stock Return (on Companies Listed on the Lq45 Index on the Indonesia Stock Exchange in 2011-2015. eProceedings of Management, 3(3).

Ningrum, D. A., \& Leny, Suzan. (2015). The Influence of Return on Equity (ROE), Sale Growth, and Earning per Share (EPS) to Stock Price (Case Study On Coal Mining Company in 2010 - 2014). Journal of Management 2(3). 3287 - 2389.

Nurminda, A., Deannes, I., \& Annisa, N. (2017). The Influence of Profitability, Leverage, and Firm Size Toward Firm Value (Study of Manufacture Companies Goods and Foods Sub Sector Listed in Indonesia Stock Exchange 2012 -2015). Journal of Management 4(1), 542 - 549.

Oktrima, B. (2017). Effect of Profitability, Liquidity, and Capital Structure on Company Value (Empirical Study of PT Mayora Indah Period 2011 - 2015). Journal of Security, 1(1), 98 - 107.

Pirie, S., \& Smith, M. (2008). Stock prices and accounting information: evidence from Malaysia. Asian Review of Accounting, 16(2), 109-133. doi: 10.1108/13217340810889924

Revelli, C., \& Viviani, J.-L. (2013). The link between SRI and financial performance: effects and moderators. Management international/International Management/Gestiòn Internacional, 17(2), 105-122.

Setyorini, Maria, M. M., \& Andi, T. H. (2016). The Effect of Return on Assets (ROA), Return on Equity (ROE), and Earning Per Share (EPS) Against the Stock Prices of Real Estate Companies on the Indonesia Stock Exchange (Case Studies of 20 Companies in the 2011 - 2015 Period). Journal of Management, 2(2), 6 - 9.

Slager, R. (2015). SRI Indices and Responsible Corporate Behavior: A Study of the FTSE4Good Index. [Article]. Business and Society, 54(3), 386-405. doi: 10.1177/0007650314557933.

Sudiyatno, B., \& Elen, P. (2010). Tobin's Q and Altman Z - Score as Indicators of Measuring Company Performance. Journal of Accounting, 2(1), $10-13$.

Sugiarto, M., \& Perdana, W. S. (2017). Effect of Macroeconomic Indicators, Financial Performance, and Governance on Company Value in the Property Sector on the Indonesia Stock Exchange. Journal of Economics and Business Aseanomics (JEBA), 2(2), 288 - 312.

Suryana, A., \& Nila, F., N. (2018). The Effect of Executive compensation on ROA and Tobin's Q with Company Age and Size Control Variables (Study on Manufacturing Companies Listed on the Indonesia Stock Exchange for the 2012-2016 Period). Journal of Business Administration, 60(2), 38 - 42.

Suwardjono. (2016). Accounting Theory : Engineering Financial Reporting. Third Edition.Yogyakarta : BPFE.

Verschoor, C. C. (1998). A study of the link between a corporation's financial performance and its commitment to ethics. Journal of Business Ethics, 17(13), 1509-1516. 